\title{
Exploring Curricular Internships in Italy: Towards Entrepreneurial Universities
}

\author{
Maddalena della Volpe ${ }^{1}$, Alfonso Siano ${ }^{2}$, Agostino Vollero ${ }^{2}$, Francesca Esposito ${ }^{2}$ \\ ${ }^{1}$ University of Suor Orsola Benincasa, Naples, Italy \\ ${ }^{2}$ University of Salerno, Italy \\ Correspondence: Francesca Esposito, Department of Political, Social and Communication Sciences, University \\ of Salerno, Via Giovanni Paolo II, 132-84084 Fisciano (SA), Italy. E-mail: fraesposito@unisa.it
}

Received: June 23, $2016 \quad$ Accepted: July 7, $2016 \quad$ Online Published: August 12, 2016
doi:10.5539/ibr.v9n9p150
URL: http://dx.doi.org/10.5539/ibr.v9n9p150

\begin{abstract}
This paper presents a database of the curricular internships offered by all Italian universities in different Courses of Studies (CoS), in the light of the challenge faced by university managers in shifting their institutions to a more entrepreneurial mode within a "triple helix approach" that highlights the relation between universities, government and enterprises. We built our database considering University Credits (UCs) attributed during the academic year 2014/15, consulting the websites of the Italian Ministry of Education and the official websites of 91 Italian universities. Although 3139 out of $4428 \operatorname{CoS}(70.89 \%)$ offer curricular internships, these learning experiences in most scientific areas have a minor role in learning paths. These results also highlight the general sense of mistrust Italian universities place in the entrepreneurial world. The paper should enable university managers and policy makers to evaluate the activities carried out during curricular internships in Italy. The paper also provides useful insights to redefine the CoS offer in Italy. Data could be collected and updated yearly in order to monitor how the scenario is evolving. This paper contends that internships should be placed within the teaching mission in order to have an impact on entrepreneurship.
\end{abstract}

Keywords: courses of studies, entrepreneurial university, internship, Italy, triple helix

\section{Introduction}

Cennino Cennini (1370-1440), a painter and author of the well-known essay on painting Il libro d'arte, wrote that to become a painter, it is necessary to be employed in a workshop for at least 13 years, starting in childhood (Cennini, 1859). The idea of apprenticeships to develop skills related to professions can be traced back to the Middle Ages. Until the Renaissance, at least seven years were usually necessary to both acquire practical skills and to absorb the tacit knowledge involved. The English apprenticeship system was regulated in 1562 with the Statute of Artificers. During the $17^{\text {th }}$ and $18^{\text {th }}$ centuries, the apprenticeship system became essential to socialise, educate and develop young people for crafts and professions (Burke \& Carton, 2013).

Considering that internships are a centuries-old phenomenon, Holoyak (2013) quotes Perrin (2012) in highlighting that by the end of $19^{\text {th }}$ century, "true" internships had started appearing in medical schools. The internship differs from apprenticeship that instead refers to a period during which an individual learns a practical part of an art or a craft. Burke and Carton (2013) highlighted how apprenticeships were maintained in Great Britain, but not in the United States, where they were replaced by the secondary schools for the development of workforce. This was a similar situation in Italy, in the 1970s, when professional training ran parallel to school and university education (della Volpe, 2009). Internships have only been separated from professional training since the $1990 \mathrm{~s}$.

Thus, internships have become part of an educational methodology aimed at familiarizing the student with the world of work in general and of enterprises in particular. A first step is making internships mandatory during Courses of Studies $(\mathrm{CoS})$, within solid projects, developed in collaboration with external actors. We started from this initial hypothesis, following Kahn (2012) and Roper (2013), to collect and analyse the conditions of mandatory internships among all Italian universities, in order to provide an overall picture of their development. Although internships are well established in US universities and are becoming so in the UK (Holoyak, 2013), for other countries, data are fragmentary. In Italy, curricular internships were only started at the end of the 1990s 
(della Volpe, 2009). We contend that the quantity of mandatory internships in CoS of any kind, with a significant percentage of recognized university credits (UCs), should be considered as one of the basic conditions of entrepreneurship orientation in a university as well as to improve students' performance and their employability.

This paper is structured as follows. In the next section, we present the conceptual foundations - i.e. the triple helix approach - that will be used to analyse the rise of the entrepreneurial university. A critical literature review of the significance and the role of curricular internship is then presented. Five thematic groups of articles were identified to substantiate the link between curricular internships and the entrepreneurial university. We theoretically demonstrate that the internship is a fundamental component both in the learning process of the student and in developing an entrepreneurial orientation for universities. A complete database of curricular internships offered by all Italian universities was developed, thus revealing that curricular internships have played a minor role in Italian learning paths. The paper concludes by offering policy implications and suggesting different avenues for future research.

\section{The Enterprise in the Triple Helix: The Rise of the Entrepreneurial University}

According to Etzkowitz (1990), the first academic revolution happened when the medieval university, centred on teaching, extended its role by generating knowledge, and placing research and teaching side by side. The second academic revolution began in 1980 with the introduction of the so-called third mission. This concerns all activities related to the use of knowledge created by universities to enhance social, economic and cultural development. From here new hybrid structures (e.g. scientific and technological parks, startup incubators, offices of technological transfer) were set up, aimed at promoting academic knowledge at an economic level.

According to Etzkowitz's (1990) triple helix model, university, government and enterprises are the three actors of innovation, on which the transfer of knowledge as economic good depends. However, the efficacy of this model is based on the interactions among parties. To start this process it is necessary to create a common ground for listening and dialogue, overcoming distances between research and enterprise, and between knowledge and practicality. The increase in symmetrical relations between universities, enterprises and the government that hosts them implies that each subject plays diverse roles, adopting a synergic behaviour, without forgetting its main function, but favouring the transfer of knowledge and technologies (Etzkowitz, 2003; Narayanan, Olk \& Fukami, 2010; Alfonsi \& Dilorenzo, 2012; Bak, 2014; Guerrero, Cunningham \& Urbano, 2015; Kalar \& Antoncic, 2015). However, the achievement of this integration between the three actors involves overcoming numerous barriers. First, the triple helix process entails each subject having to change from within, thus recognising the specific role of the other components (Coduras Martinez, Levie, Kelley, Sæmundsson \& Schøtt, 2010).

The concept of the entrepreneurial university is well known in the literature (Slaughter \& Leslie, 1997), going back to the first definitions by Etzkowitz (1983): "universities that are considering new sources of funds like patents, research under by contracts and entry into a partnership with a private enterprise". Later, Etzkowitz (2003) revises his definition, considering entrepreneurial university as "a natural incubator [...] to initiate new ventures: intellectual, commercial and conjoint". Guerrero et al. (2015) give a more advanced definition: "[...] entrepreneurial university serves as a conduit of spillovers contributing to economic and social development through its multiple missions of teaching, research, and entrepreneurial activities". According to the authors, entrepreneurship contributes to the growth of new enterprises thanks to knowledge spillover, to the increase in competition and diversity.

In this article, we refer to a broad concept of entrepreneurship, including aspects related both to small business management and to general management, despite having specific theoretical and practical differences, as sustained by Gorman, Hanlon and King (1997) and Alberti (1999). We also share Schulte's vision (2004), which affirms that all university students should have the chance to get in touch with the business world in order to have a practical oriented education, although most students are not likely to set up their own entrepreneurial activity. Among the definitions of entrepreneurial university, three key aspects are focused on teaching, research and entrepreneurship (relationships with enterprises, education to management and entrepreneurship, services and offices focused on relationships with societies and enterprises), and performances are mostly evaluated according to the number of patents and licenses and/or the number of spin-offs (Powers, 2004).

Todorovich, McNaughton and Guild (2011), for Canada, and Riviezzo and Napolitano (2014) for Italy, studied the entrepreneurial orientation in university departments with web-based questionnaires. Unlike the traditional university, the evaluation of an entrepreneurial university is mostly based on results in terms of local (regional), national and/or international economic growth. However, the transformation of a research project into a commercial product depends on several factors, as highlighted by Gras, Lapera, Solves, Jover and Azuar (2008). 
An important role is that of human capital (Becker, 1975), which is taken into consideration by both Todorovich et al. (2011) and Riviezzo and Napolitano (2014), who consider the "degree of cooperation between the department and enterprises, on different levels: the involvement of teachers, students and the departmental structure as a whole". As for students, since Todorovic et al. (2011) did not include the availability to attend an internship among their questionnaire prerequisites, neither did Riviezzo and Napolitano (2014).

Regarding the 147 English universities in the so-called Russel Group (Molas-Gallart et al., 2002), Guerrero et al. (2015) affirm that among the teaching characteristics of entrepreneurial universities "undergraduates have opportunities to engage in research themselves [...]. There are also programs for work-based learning, internships in coveted professions and tailored guidance to help students consolidate the skills which are valued by employers". Thus, internships are mainly seen as a bridge to the professional world. In agreement with Narayanan et al. (2010), we consider "internships as a knowledge transfer process". Therefore, the university has to "facilitate two-way knowledge transfer", accepting that business is also capable of producing knowledge, especially from the human capital point of view (Narayanan et al., 2010). In Table 1, we present the above-mentioned criteria in the definition of an entrepreneurial university.

Table 1. Criteria in the definition of an entrepreneurial university

\begin{tabular}{ll}
\hline Teaching activities & $\begin{array}{l}\text { Impact on economic notions about human capital (the stock of } \\
\text { competencies, knowledge, abilities and skills gained through } \\
\text { education and training: work-based learning, internship) } \\
\text { Two-way knowledge transfer } \\
\text { generation, transfer, and commercialization of new knowledge } \\
\text { (copyrights, patents, licenses, and trademarks) }\end{array}$ \\
Research activities & $\begin{array}{l}\text { Creation of new companies, contribution to output and growth by } \\
\text { serving as a conduit for knowledge spillovers, increasing } \\
\text { competition, and injecting diversity }\end{array}$ \\
\hline
\end{tabular}

Note. Adapted from Narayanan et al., 2010 and Guerrero et al., 2015.

Internships in universities involve the human capital factor (students, professors and employees) which, as we have already said, is decisive in transformation processes. The involvement of students in practical activities from the start of their bachelor degree in a social and entrepreneurial context leads to the development of knowledge of work and entrepreneurship in broad terms, which favours the recognition of work as a form of knowledge. Mayhew et al. (2012) underline the role of "innovative entrepreneurship and its related educational practices and experiences, especially in the context of challenging economic times". Evidently, for this to happen a high percentage of teachers and researchers need to have a favourable and proactive attitude towards the third mission, and current academic and ministerial policies need to converge towards the second academic revolution (Etzkowitz, 1990).

\section{Internship and Entrepreneurial University}

The high level of heterogeneity in research on the role of internship in university makes it difficult to define the precise boundaries of this field of study. Thus, we focused upon a purposive rather than exhaustive method in the sampling of relevant studies. This allowed us to have a thematically driven approach to the review of literature (Short, 2009), which seems more apt to our research aims. To this end, firstly we consulted the ISI Web of Science to identify the published studies with internship as a keyword and obtained more than 43000 results (about 24000 were between 2000 and 2015), of which more than 5000 were related to university and 7000 to the medical sector. More than 10000 papers regarded graduate and post-graduate students, and only 490 considered undergraduate students, of which only 100 papers were not dedicated to the medical sector. In the same database, we searched for the topic entrepreneurial university and obtained 1397 titles, of which only 13 were also related to internship, within the 2004-2015 period. We did not consider publications regarding medical internships, since the tradition in this field is very specific and rooted, and not descriptive of the use of internships as a means to facilitate the transformation of universities towards a more entrepreneurial mode.

To sum up, first we selected approximately 100 papers from the ISI Web of Science starting with internship and refining with additional topics such as undergraduate and non-medical, and 13 papers based on the topics, internship and entrepreneurial university. After a close reading of all the abstracts of these 113 papers, we chose the most significant reported experiences. Then, in the selection procedure of the final dataset, we searched for books and papers on Google Scholar and Google Books, using topics such as undergraduate internship or entrepreneurial university as the input for queries. Again, we searched papers and documents with topics in Italian such as "stage curriculari", "università", "tirocini", on Google Scholar, Google Books and Google in general, to describe and represent the situation in Italy. Finally, we selected all the literature dealing the themes of internship according to a triple helix approach. 
Among all the publications taken, we created five thematic groups representing 77 studies analysed, which allowed us to reach the "theoretical saturation" recommended by Bowen (2008).

1. There were 15 studies and research papers on internship from the perspective of the students' experience with the real professional world. Renganathan et al. (2012) presented the case study of the University of Malaysia, which offers an internship program that lasts 8 months in enterprises, carried out during the course of studies. The student perception of the experience was positive and success factors were identified as the practical and administrative effort made by the hosting structures. The program, which enables students to experience a real professional environment before graduating, encourages a participative approach, based on direct involvement, rich learning opportunities, and the chance to apply the theoretical knowledge acquired in previous years. Thus, learning becomes a two-way process, based on knowledge and experience. In addition, while university classes are uniform, the environment of learning in enterprises is different for each student. This is positive, since the market no longer just requires graduates with a high level of theoretical knowledge, but skills that will enable them to succeed in a work environment, i.e. soft skills: the ability to work in a team, problem solving, communication, leadership, negotiation, oral and written presentations, among others. Carter at al. (2016) demonstrate that internships (and other co-curricular experiences) have positive effects on engineering students' assessment of their professional skills (teamwork, communication, and leadership).

2. There were 12 studies and research papers on internships from the perspective of the employer and placement. The Italian studies included research papers from the consortium Alma Laurea, the CRUI Foundation, ANVUR (National Agency for the Evaluation of Universities and Research Institutes) and Bocconi University in Milan with the CEMS (Community of European Management Schools) publications: in these works, the relationship between internship and employment was analysed on various levels. In a study carried out at the West Chester University in Pennsylvania Gault, Leach and Duey (2010) highlight the value of the student's participation in the internship as a key factor to her/his learning experience, as well as a contribution to her/his employability in the job market. University students with internship experiences are perceived as being better prepared Kim, Kim and Bzullack (2012). A study was carried out among 500 AACSB (Association of Advance Collegiate Schools of Business) accredited in the USA as universities that organise their internship programs around variables such as credits, prerequisites, hours of work required, activities carried out. The conclusions were to: (a) make the internship a required course; (b) encourage tutors of hosting subjects to actively participate in the internship program; (c) have the students write weekly diaries; (d) have students do presentations in class on problem solving experienced during the internship; (e) establish the right prerequisites to improve the experience; (f) dedicate full-time resources to the supervision of internship students in order to monitor, solve problems and facilitate participation. Sascha, Praveen Parboteeah and Achim (2013) analysed 25 university departments in Germany, through the study of 1530 business students and 132 professors. They showed that an entrepreneurship education through internships also facilitates job placement, especially for male students. Friedmann et al. (2004) underline that in a 2004 study by Spiegel, American Online (AOL), McKinsey \& Company, conducted on about 50000 German university students in relation to 15 disciplinary areas, it appeared that getting the degree, the most important success factors were the internship, and periods abroad other than exam marks. Burke and Carton (2013) wrote about unpaid internships, highlighting the advantages for both parties: interns and hosting subjects. In fact, the hosts gain the fresh perspective the intern brings to the job, and the intern gains skills and knowledge acquired before entering the working world. An unpaid internship also has a legal and ethical justification, especially if the university monitors her/his progress, provides support and gives feedback. Daugherty (2011) focused on the differences in expectations between interns and employers: the interns want to develop their skills guided by the employers, while the employers prefer not to give precise directives, but to let the interns manage themselves independently.

3. There were 8 studies and research papers on internships from a more general perspective in terms of the relationship between university and enterprises as a tool for economic development. If we look at Latin America, Vega-Jurado, Fernandéz-de-Lucio and Huanca (2008) underline that, in Bolivia, the productive sector has problems keeping up with the technological sector, being unable to adopt modern technologies within its productive processes. In this fragile scientific and technological scenario, it is important for universities to build strong relations with enterprises. The authors highlight how academic teachers perceive work experiences in firms (meaning internships) for students as the most natural instrument to establish real cooperation with the world of work, leading to the creation of hybrid structures. Frasquet, Calderòn and Cervera (2012) analyse the relationship between universities-enterprises through internship programs in the social sciences, at the University of Valencia in Spain. According to the authors, communication between universities and enterprises is key in building a strong relationship, aimed at solving conflicts, pursuing objectives and creating value by uncovering 
new opportunities. The internship (paid in only $30 \%$ of cases) plays an important role in establishing a contact point with enterprises, in the direction of knowledge transfer: an experimental program is presented within the area of social sciences, which involves 8000 students per year. Positive evaluations on the internship's ability to overcome the gap between theoretical education and practical experience and fostering economic development mostly come from Mihail (2006), regarding Greece.

4. There were 28 studies and research papers on internship as one of the components in an entrepreneurial university. It is worth noting here that the US, with the Bayh-Dole Act of 1980 has encouraged universities to invest in infrastructure to support entrepreneurship, which has generated increasing focus on the triple helix approach. Bak (2014) and Pavlin (2014) report on the relationships between universities and 396 companies within the framework of university-business cooperation in Bulgaria, Hungary, Poland, Slovenia and Spain. They found that enterprises primarily encourage a practical orientation to teaching as much as the development of internships for undergraduates and traineeships for graduates. In 2004 in the UK, the National Council of Entrepreneurship in Education (NCEE) was set up, which with yearly awards promotes entrepreneurial universities, which are characterized, among other factors, by internship and traineeship programs. Graham (2014) reports on a study funded by the American MIT on the world's top ten universities where transformations are taking place in terms of entrepreneurship and innovation through a wide variety of instruments, such as initiatives that encourage students to get in touch with the entrepreneurial world during their studies. A particular field of analysis is represented by universities with internships aimed exclusively at entrepreneurial methodology (e.g., the University of Chicago, Booth School of Business - Polsky Center for Entrepreneurship and Innovation). Another particular case are internships offered by business Schools, Masters in Business Administration and other similar public or private institutions. These institutions were not included in this article, which only focuses on $\mathrm{CoS}$ in Italian universities.

5. There were 14 studies and research papers on the entrepreneurial university, with no specific references to internships, but to topics such as experiential learning, entrepreneurial teaching methodology or to the general context of real-world immersion teaching. We have already discussed the concept of the entrepreneurial university, thus here we only refer to the report by the WEF (Schwab, 2013) on competitiveness, which highlights that Italy is considerably below average compared to other European countries in relation to the post-graduate educational system, in terms of sensibility towards entrepreneurial factors.

Table 2. Thematic groups: internship and entrepreneurial university

\begin{tabular}{|c|c|}
\hline Thematic group & Authors \\
\hline $\begin{array}{l}\text { Internship from the perspective of the } \\
\text { students' experience }\end{array}$ & $\begin{array}{l}\text { Taylor (1988), Fayolle et al. (2006), Cannon and Franck (2009), D' Abate } \\
\text { (2009), Gault et al. (2000), Hurst and Good (2010), Hynie et al. (2011), } \\
\text { Renganathan et al. (2012), Cameron (2013), Dombrowski et al. (2013), } \\
\text { Hoyle and Goffnett (2013), Holyoak (2013), Cheong et al. (2014), Binder et } \\
\text { al. (2015), Carter at al. (2016) }\end{array}$ \\
\hline
\end{tabular}

Internships from the perspective of the Friedmann et al. (2004), CEMS (2010), Gault et al. (2010), Daugherty employer and placement (2011), Alfonsi and Dilorenzo (2012), Kim et al. (2012), Burke and Carton (2013), Sasha et al. (2013), Tholen et al. (2013), Alma Laurea (2014), ANVUR (2014), CRUI Foundation (2014)

Internship as bridge between university and Sabato and Botana (1968), Mihail (2006), Vega-Jurado et al. (2008), della enterprises Volpe (2009), EYF (2011), Ciapetti (2012), Frasquet et al. (2012), Shin et al. (2013)

Internship in an entrepreneurial university

Dilts and Fowler (1999), Mann and Blum (2004), Frank (2005), Fayolle and Redford (2007), Poh-Kam et al. (2007), Gary et al. (2008), Narayanan et al. (2010), Ilsbroux and Sammels (2011), McDonald et al. (2011), Meyers and Pruthi (2011), Galeano et al. (2012), Gao and Gao (2012), Khan (2012), Ilsbroux (2012), De Grez and Van Lindt (2012), Dodescu et al. (2013), Graham (2014), Roper (2013), OIEEDA and NACIE (2013), Pavlin (2014), Bak (2014), Coyle et al. (2014), Nadan (2014), Nitu-Antonie et al. (2014), Walshok and Shapiro (2014), ACEI (2015), Chang et al. (2015), Guerrero et al. (2015)

Entrepreneurial university, with no specific Etzkowitz (1983, 1990, 2002, 2003), Clark (1998), Etzkowitz and reference to internships Leydesdorff (2000), Guerrero et al. (2006) Guerrero and Urbano (2012, 2014), Coduras et al. (2010), Kirby et al. (2011), Leydesdorff (2012), Schwab (2013), Kalar and Antoncic (2015)

In spite of the interest generated by the topic, as we have seen the research is often fragmented and quantitatively weak, although precise and significant aspects of internships are highlighted in relation to all the actors of the triple helix. Most of the papers are published by journals dedicated to education innovation, while few are aimed at scholars in business management. There is also a lack of scientific publications that present an overall and 
statistically valid picture of how many universities, in different countries (in Italy, Europe and the rest of the world), offer curricular internships within different CoS. The analysis of the literature helps us to gain further understanding of how curricular internships improve the learning process for the students, allowing them to acquire soft skills and at the same time improving their future placement in the job market. However to achieve these results, the internship needs to be a mandatory part of the educational process, and monitored both by the student's own university and the host university, on the basis of an appropriate educational project. In Italy, internships are sometimes only voluntary options, offering students the alternative of learning the necessary UCs by attending a laboratory course $\mathrm{e}^{\mathrm{ii}}$. To be effective, instead, internships should play a major role in teaching activities and be embedded throughout the learning paths, with the substantial recognition of attributed university credits (UCs in this article, in Italian CFU Credito Formativo Universitario) in relation to the CoS. The duration of internships mostly depends on the different countries' laws and regulations. In Italy, it oscillates between 1 and 12 months, in the US between 10 weeks and one semester. In Italy, each CoS attributes a number of UCs for each exam, laboratory, and thesis to a maximum of 180 credits for three-year degrees, 120 for biennial Master's degrees, 300 for five-year degrees, 360 for six-year degrees (medicine and surgery). Each UC has an average value of 25 hours of work, of which 8 are assigned to classes and 16 hours to home study. An exam that is considered to be fundamental can be worth from 9 to $12 \mathrm{UCs}$, which correspond respectively to 225 and 300 hours.

In our analysis, we focused on the number of UCs given for internships and the percentage they represent compared to the total number of UCs required for the degree. The number of recognized UCs for an internship in Italy involves an exact match in hours of work; however, this can vary from one CoS to another. We therefore decided to include all Italian universities in order to identify and quantify which universities and $\mathrm{CoS}$ are currently working in this direction, also considering the number of UCs given for curricular internships.

\section{Methods}

The research objective was to identify all the internship offers available in Italian universities for the academic year 2014-2015, to analyse it critically, since neither the Italian Ministry of Education nor other sources have ever systematically collected these data. First of all, of the $4428 \mathrm{CoS}$ available in Italian universities, we identified 3139 active ones offering curricular internships. We then analysed the corresponding websites of 91 Italian universities, which distribute CoS, using the list published by the Italian Ministry of Education ${ }^{\text {iii }}$. We then associated the internships with their respective UCs. We thus built a data set constituted by the 10 records shown in Table 3.

Table 3. Sample of the records of the dataset

\begin{tabular}{llllllccccc}
\hline University & Course of Study & Class & $\begin{array}{l}\text { Scientific } \\
\text { Area }\end{array}$ & City & Region & Internship & UC & $\begin{array}{l}\text { Course } \\
\text { Study UCs }\end{array}$ & $\begin{array}{l}\text { ofeografical } \\
\text { Area }\end{array}$ \\
\hline Bocconi & $\begin{array}{l}\text { Social and } \\
\text { Economic Science }\end{array}$ & LM-56 & ME & Milan & Lombardia & By choice & 3 & 120 & North \\
\hline
\end{tabular}

The first field contains the name of the university', which in the database are presented in a correspondence table. The second field contains the CoS title. The third one shows the degree class defined by the Ministry of Education ( $\mathrm{L}$ followed by a number for three-year degrees, LM followed by a number for two-year courses and single cycles five-year and six-year degrees). The fourth shows the scientific area, according to an amalgamation of disciplines identified in our classification (See Appendix A for details of Scientific Areas). The fifth and the sixth fields show the city and the administrative region where the university is located. The seventh refers to the nature of the internship: mandatory, by choice, absent. The eighth field contains the number of UCs required to obtain the qualification. The tenth shows the geographical area, divided into north, centre, south and islands, according to the ministerial classification. From this data set, we have made an online database (http://dsc.unisa.it/stage/provaindex.asp) which allows freely researching on the more important fields obtaining different kinds of graphs. The Italian Ministry of Education indicates degree classes with official initials and titles. Universities can modify the CoS name, however the Class stays the same. Starting from degree classes, we created wider scientific areas. We decided not to adopt the four subdivisions (Health, Scientific, Social, Humanistic) chosen by the Ministry of Education, as it is too broad.

The way we aggregated scientific areas needs a further clarification. For example, the three-year degree class L-23 concerns construction engineering and therefore is placed within Engineering (ENG). However, in some cases, despite being named Engineering and Techniques for Construction and Architecture, we have left it in the ENG area, even though there are aspects that belong to Architecture and Design (AR). The wide and diversified area of Mathematics, Physics, Biology and Chemistry (MS) includes Medical and Pharmaceutical Biotechnologies, which could have been included in the area of Medical, Health and Sport Sciences (MED). The scientific area named 
Communication Sciences (CS) includes three-year degree classes with ministerial initials L-20 (Communication Sciences), which constitute the majority, L-12 (Linguistic and Intercultural Communication), L-40 (Digital and Communication Cultures), L-31 (Web and Media Technologies), and the interclass L-3/L-20 (Communication and Disciplines of Art, Music and Entertainment - DAMS). The Political and Social Sciences area (PSS) typically includes the CoS of Sociology and Political Sciences, while the Social Sciences area (SS) is relative mostly to those $\mathrm{CoS}$ that train social assistants. The database has been completed with each degree class and researchers will be able to redefine the scientific areas that are more suitable to her/his specific research.

\section{Curricular Internships in Italian Universities: Data Analysis}

Consulting the official websites of 91 Italian universities, we created Figures 1 and 2, which represent the number of active internships, by geographical area, scientific area and the kind of $\mathrm{CoS}$ (three-year, biennial masters, single cycle including master's degrees of five years and master's degrees of six years). We then created Figure 3 in which we considered not only the number of internships in each scientific area, but also their corresponding UCs, according to the previously formulated hypothesis that the higher the number of UCs the stronger the investment in internship activities by universities in relation to the scientific area. We then unified the number of UCs attributed in three ranges, according to the ANVUR classification (2013): Max range: from 13 and more UCs, Med range: from 6 to 12 UCs, Min range: from 1 to 5 UCs. Finally, we created Figures 4 to 6 where we considered the average UCs percentage compared to the total number of credits necessary for the degree in different Courses of Studies: 180 in three-year undergraduate, 120 in master's degrees and 300 or 360 in single cycle master's degrees.

\subsection{Curricular Internships}

As highlighted in Figure 1, 29.1\% of CoS do not provide internships. Internships are offered more in three-year courses (78.5\%) than in biennial master's degrees (62.6\%): of which, $37.3 \%$ do not offer internships.

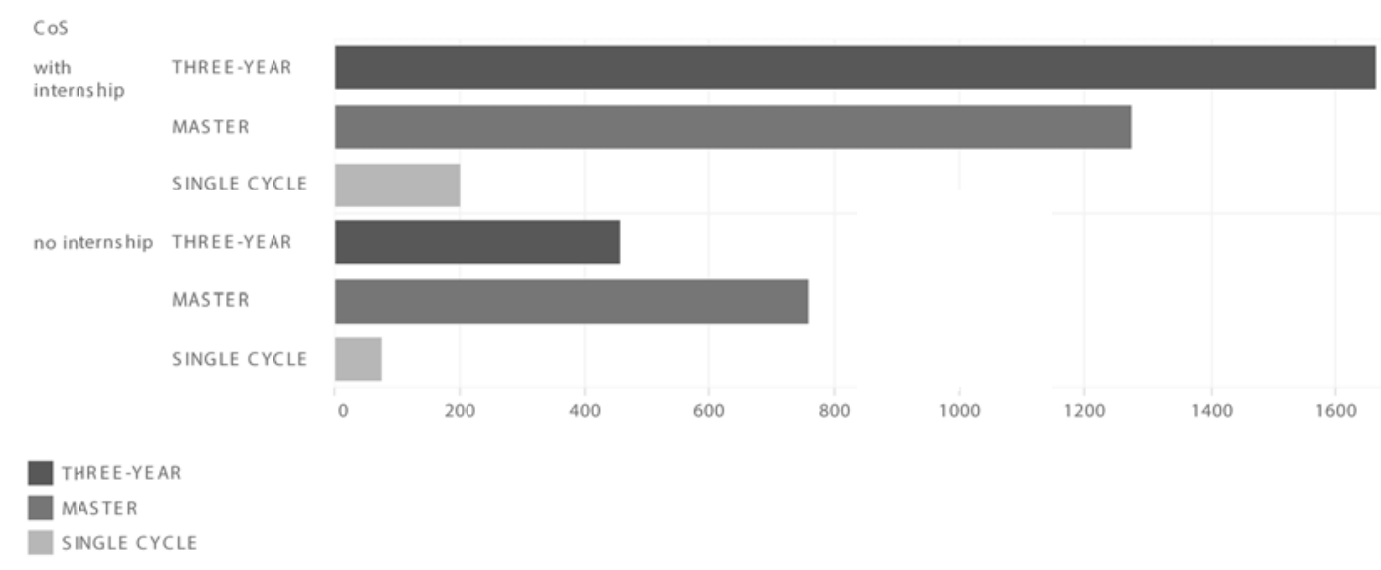

Figure 1. Italian universities $\mathrm{CoS}$ with and without internships

Ninety-one universities offer curricular internships, mandatory or by choice, both on three-year degrees and biennial master's degrees or single cycle master's degrees. They are distributed as follows: 33 in the north, 32 in the centre, and 26 for south and islands. We grouped the internships according to geographical area, with a higher concentration of curricular internships in the North $(43 \%)$ than in the Centre $(29.3 \%)$ and South $(27.6 \%)$. Note that there are fewer universities in the South and although the Centre has a similar number of universities as the North, it has fewer curricular internships, with 13.7 points less than in the North.

Figure 2 reports the scientific three-year, master's and single cycle degrees with internships (excluding those with no internships). The first section in Figure 2, relative to three-year degrees shows 2120 active CoS, of which 456 (21.5\%) do not offer internships, $1446(68.2 \%)$ offer mandatory internships, and $218(10.2 \%)$ by choice. The interest in internships (mandatory or by choice) is represented by $1664 \mathrm{CoS}(78.4 \%)$. The courses attributing more importance to mandatory internships are MED (98.5\%), SS (88.4\%), AGENS (88.2\%), and ED (87.5\%). On the other hand, the CoS that are not inclined to offer mandatory internships are PSY (35.9\%), LIT (41.6\%), PSS (41.7\%) and ENG (43.2\%). These latter disciplinary areas offer internships by choice but, more often than not, do not require any internship. PSY, for example, offers $23 \%$ internships by choice and $41 \%$ with no internship at all.

The middle section of the Figure, shows that out of 2021 active master's degree CoS, 1046 (51.7\%) include mandatory internships, 227 (11.2\%) by choice, and 758 (37.5\%) do not offer any. There are 1273 (62.9\%) CoS 
that express an interest in internships. The areas that give the most importance to mandatory internships are: MED (92.9\%), AR (85\%), ED (83.6\%) and CS (78.5\%). Conversely, those less inclined to offer mandatory internships are LIT (31\%), CPS (32.4\%) and ME (35.7\%). It should be noted that courses without internships are CPS (64.8\%) and ENG (52.9\%).

The third section of Figure 2 represents single cycle master's courses for 300 UCs (5 years), and of the 202 courses active, $137(67.8 \%)$ require mandatory internships, $4(1.9 \%)$ by choice and $61(30.2 \%)$ do not require any. A total of $141(69.8 \%) \mathrm{CoS}$ express an interest in internships. Those giving more importance to mandatory internships are MED $(100 \%)$, MS $(100 \%)$ and ED $(100 \%)$. Those less inclined to offer mandatory internships are LW (20\%) and CH (40\%), which also offer no internships: LW (73.8\%) and $\mathrm{CH}(60 \%)$.

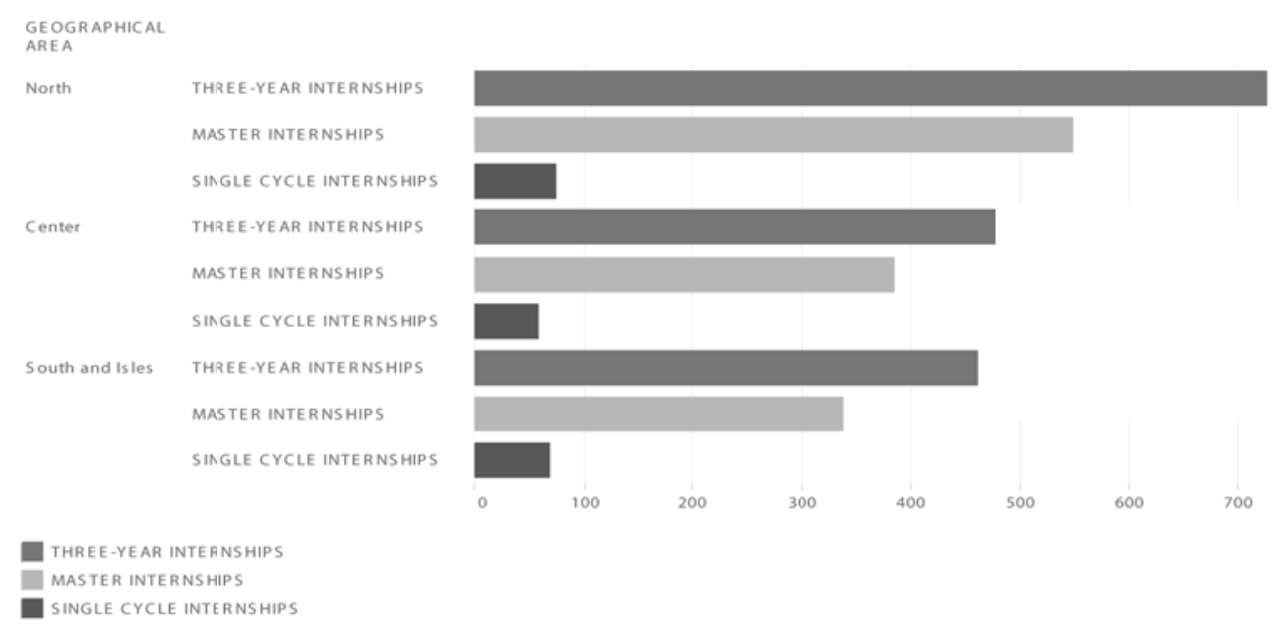

Figure 2. Mandatory internships, by choice or absent for three-year, master's and single cycle degrees $\mathrm{CoS}$

Finally, if we analyse the single-cycle courses separately that last 6 years (360 UCs), only in MED do 60 active $\operatorname{CoS}$ out of 75 offer a mandatory internship. This value represents $80 \%$ of the totality.

\subsection{Internships and University Credits}

Regarding the number of UCs in the CoS, the highest peak for three-year courses is 89 UCs, 45 for master's courses, 45 for single cycle master's courses (300 UCs) and 90 for single cycle master's courses (360 UCs).

The offer of internships in different classes is based on the total amount of internships, both mandatory and by choice, and the number of voluntary internships is reported in a different column. Therefore, for example, MED offers 470 internships in a Max range, of which, 2 are by choice.

Figure 3 shows again three sections, divided into three-year, master and single cycle degrees. The analysis for three-year courses immediately highlights the high concentration of internships in the MED area in Max range (88.8\%), with a UCs average of 53.3. This is followed by SS (73.4\%) with a 15.6 UCs average, and CPS (19\%) with a 9.6 UCs average. In the Med range: ED (80\%), with an 8.9 UCs average; $\mathrm{CH}$ (72.5\%), with a 7 UCs average; CPS (71.4\%) with a 9.6 average UCs. In the Min range: EAS (60\%), with a 4.8 average UCs; ME (48.9\%) with a 5.7 average UCs, and AR (46.1\%) with a 6.8 average UCs.

In terms of the master's courses, the MED area has a high concentration of internships (109) with a Max range of UCs (67.2\%) and a 19.6 average UCs. This is followed by PSY with 41 internships, of which 16 are in a Max range (39\%) with a 10.5 average UCs. Next is AR, with an offer of 7 internships in a Max range out of the 40 active CoS, with a percentage of $17.5 \%$ and a 9.5 average UCs. In the Med range: CC, with 13 internships (76.4\%) and a 6.8 average UCs; CS with 27 internships (75\%) with a 6.6 average UCs; and ED with 35 internships (74.4\%) with a 6.7 average UCs. Min class: AGENS with 42 internships (54.5\%) with a 6.5 average UCs; PSS with 42 internships (48.4\%) and a 7.4 average UCs; and CPS with 6 internships (46.1\%) and a 5.9 average UCs.

Regarding the third section of Figure 3, for the single cycle degree (300 UCs), MED is in first position in the Max range with $100 \%$ of their 51 internships and a 52.6 average UCs in the Max range. This is followed by ED, in the Max range with $100 \%$ of 26 internships, recording an average of 24 UCs. Likewise, MS is in Max range with $100 \%$ of 22 offered internships, with an UCs average of 30. In the Med range: AR with $76.9 \%$ and an average of 6 UCs; followed by $\mathrm{CH}(50 \%)$ with 19.8 average UCs; and LW with (41.1\%) 6.7 average UCs. Min 
range: ENG with $87.5 \%$ offering internships and 3.5 average UCs; followed by LW (57\%) with 6.7 average UCs and AR $(23 \%)$ with 6 average UCs.

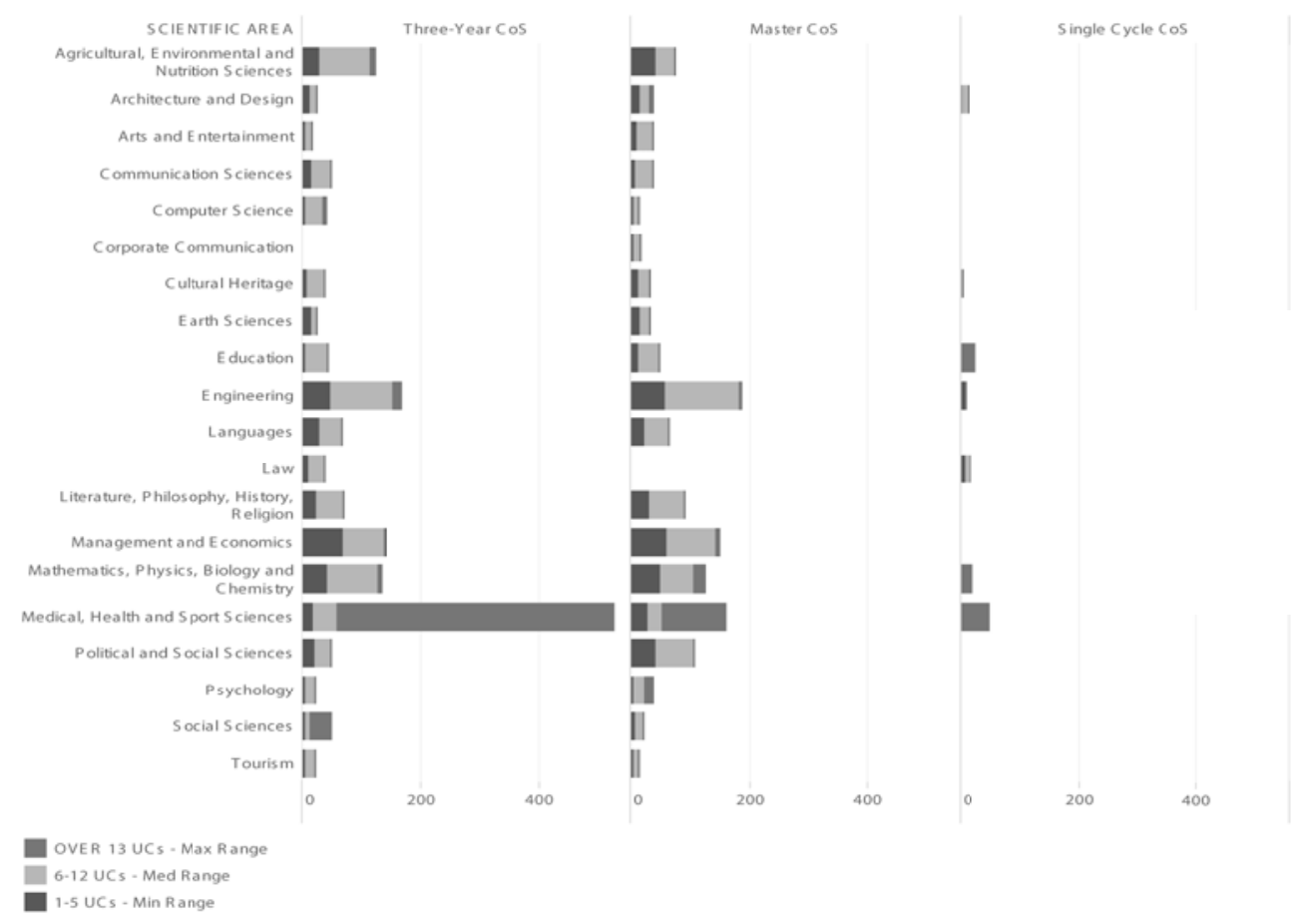

Figure 3. Mandatory internships for three-year, master's and single cycle degrees (300 UCs) by UCs average Finally with regard to single cycle of six years based on 360 UCs: only MED is in the Max range with 100\% of internships offered with the highest UCs average: 72.7.

\subsection{University Credits for Internships and Courses of Studies}

Analysing mandatory internships, we compared the percentage of attributed UCs to the total UCs among all CoS. Figure 4 highlights the strong effort by MED, in relation to mandatory internships, representing $29.6 \%$ of the entire CoS. Starting from the second position, there is a significant downward discrepancy: SS presents an average percentage of $8.7 \%$ and CPS shows $5.3 \%$. From here onwards, the percentages are between $5 \%$ and $2.7 \%$.

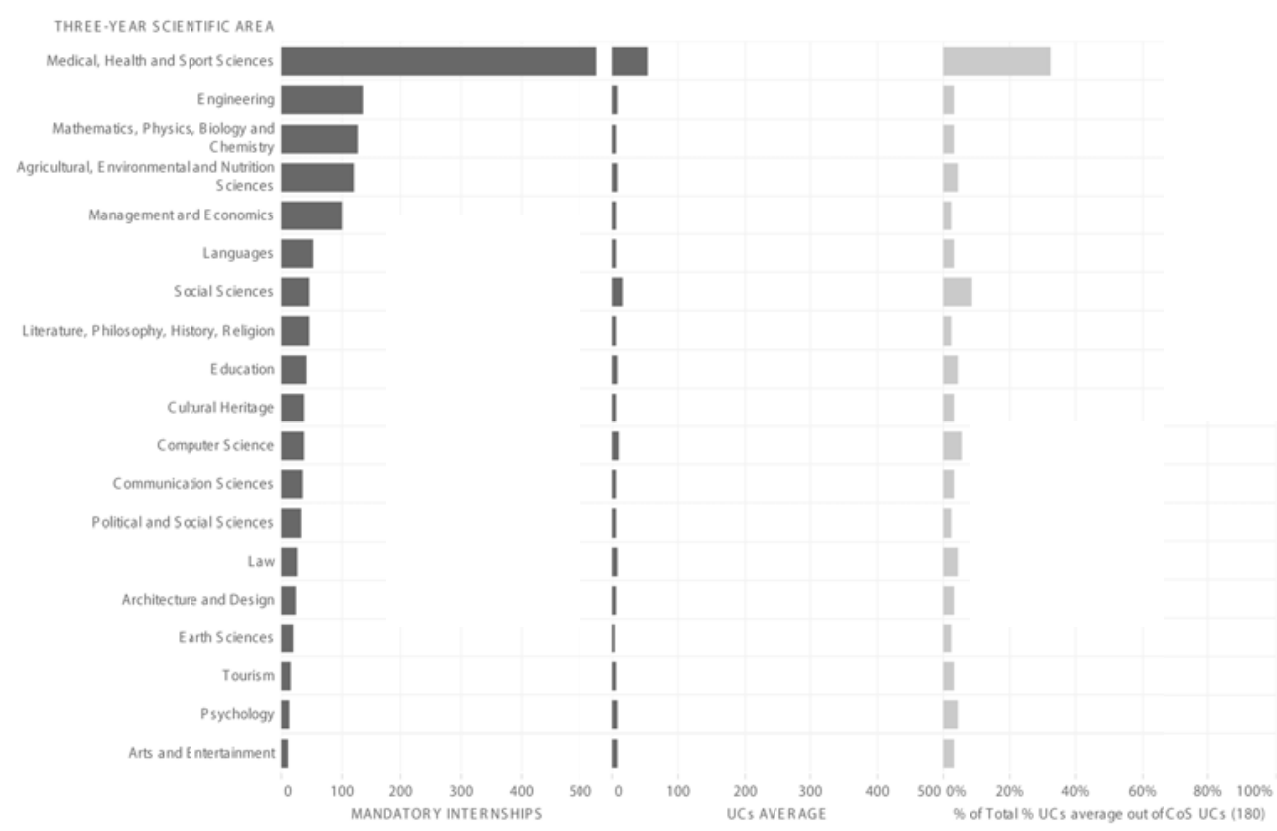

Figure 4. Mandatory internships for three-year courses by UCs average out of 180 credits 
Figure 5 is related to mandatory internships in master's degrees, and again highlights the important contribution of MED with an average of 19.4 UCs, corresponding to $16.2 \%$ of UCs in the whole CoS. From the second place on, values are much lower: MS and PSY both present an average UCs of $10.6 \%$, corresponding to $8.8 \%$ of the 120 total UCs. It should be noted that, although showing the same numbers, MS offers 116 mandatory internships, while PSY offers 40. This implies that the effort made by PSY in favour of internships is stronger. Similarly AR shows an average of 9.9 UCs and a percentage of $8.2 \%$, which corresponds to 34 mandatory internships.

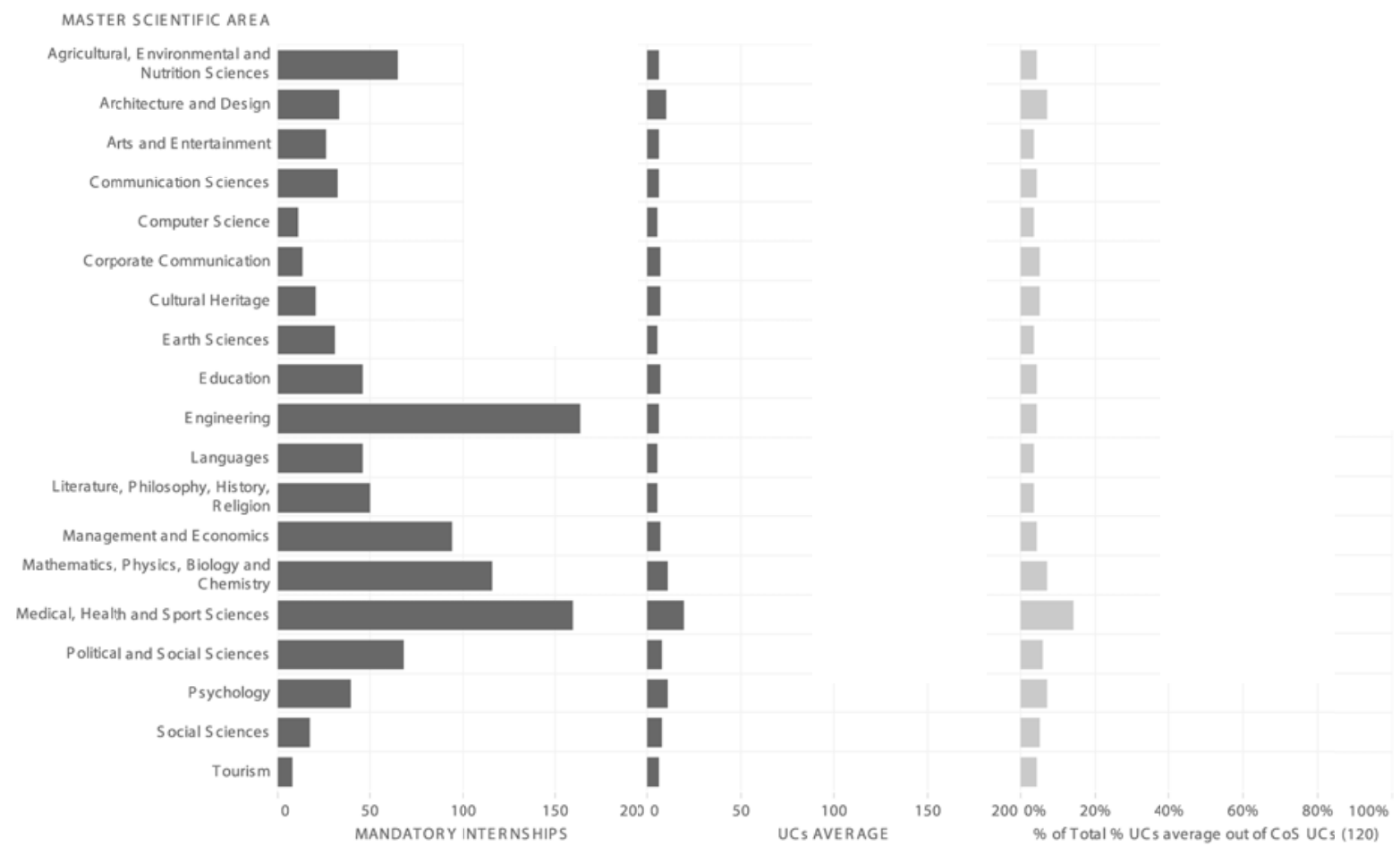

Figure 5. Mandatory internships for master's degrees by UCs average out of 120 credits

Figure 6 shows the values related to mandatory internships in single cycle master's degrees, taking into consideration both 300 and 360 UCs. Note that only the MED area includes both kinds. The 360 UCs single cycle masters in MED show their 72.7 average UCs peak, corresponding to $20.2 \%$ of internships in total. MED again, in $300 \mathrm{UCs}$ courses of studies, has a high average of $30.7 \mathrm{UCs}$, corresponding to $10.2 \%$, parallel to MS, which shows a $30 \mathrm{UCs}$ average $(10 \%)$. The MS area of $300 \mathrm{UCs}$ includes chemistry and pharmaceutical techniques, i.e. an area characterized by medical aspects. ENG, at the bottom, expresses a weak interest in internships with 3.5 average UCs, making it $1.2 \%$ of the entire $\mathrm{CoS}$.
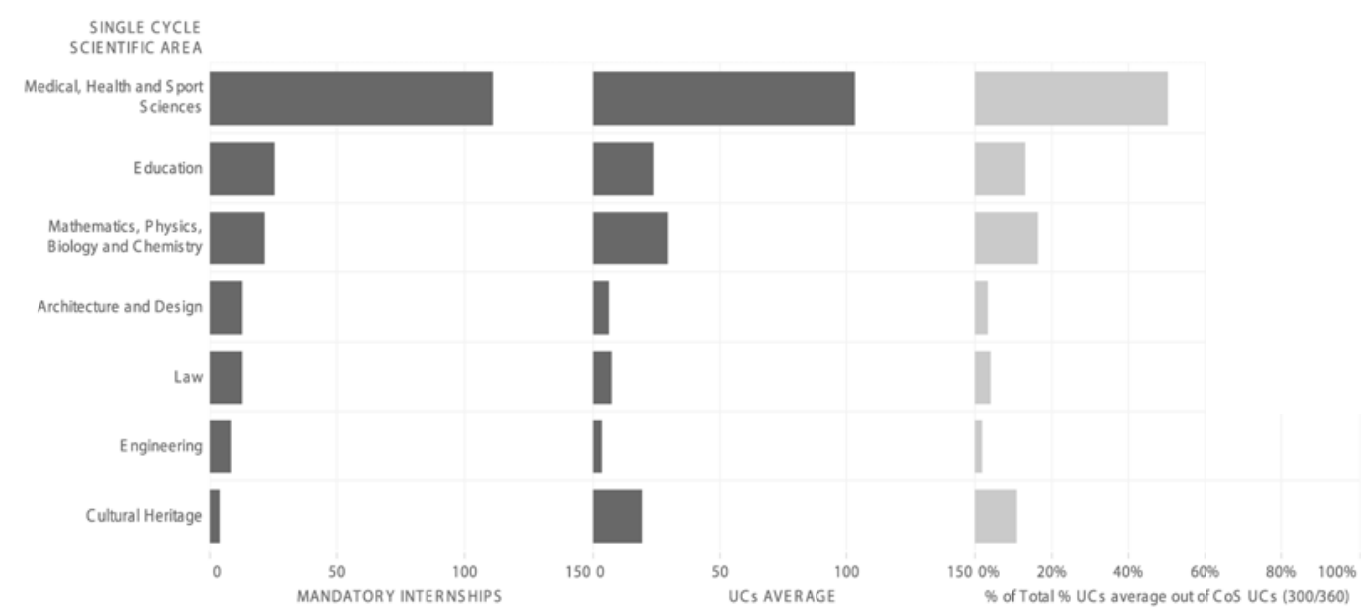

Figure 6. Mandatory internships for single cycle master's degrees by average UCs out of 300 and 360 credits 


\section{Discussion}

The data analysis highlights that the Medical area has a central role in mandatory internships $(98.5 \%)$, whether three-year, master's and single cycle courses. On the other hand, as previously said, this area has a long historical tradition of external learning activities, which is not replicated in other areas.

The area of Education gives high attention to mandatory internships, and except for single cycle master's CoS, attributes few credits to internships, which are mostly placed in the middle range. The Social Sciences area offers mandatory internships in its courses, but attributes few credits. Another relevant fact concerns MS (Mathematics, Physics, Biology and Chemistry Sciences), presenting $100 \%$ of mandatory internships by UCs in the single cycle degree. The courses involved are Chemistry and Pharmaceutical Techniques, i.e. both of medical areas. A particular case concerns Agricultural, Environmental and Nutrition Sciences, which presents $88.2 \%$ of mandatory internships during three-year cycle, but awarding few credits for them.

More in general, trends in other areas vary depending on whether they are three-year, master's or single cycle CoS. For example, in the Psychology area three-year courses offer very few internships, although in master's courses $\mathrm{CoS}$ offer $39.2 \%$ of Max range internships, immediately after MED. Architecture and Design, while offering recognition for mandatory internships (85\%) during master's and single cycle degrees $(76.4 \%)$, still attributes few credits, in line with the current trend.

In Italy, for some jobs (e.g. lawyers) it is necessary to be registered with a professional order, which requires a state exam and, in many cases, an internship or traineeship period. In Italy, there are different professional orders for the different scientific areas ${ }^{\text {iv }}$, while in other countries (Great Britain, USA, China, India, etc.) only in few areas, such as Medicine and Law, law disciplines professions. In Italy, ancient medieval corporations have maintained their power, while the Anglo-Saxon world has witnessed a broad liberalisation. In line with the European Union directives of Lisbon, in 2013 Italy began a liberalisation of access to professions, which is currently ongoing.

We have focused on this aspect because it involves the completion of studies still based on practical work, which is necessary to enable students to work in regulated professions. However, there is no clear correspondence between the necessity to be a member of a professional order and the investment in university internships, as shown by the LW and ENG data.

The analysis of Management and Economics shows how this area, which should produce future managers, offers a poor internship program: $50 \%$ in three-year cycles and 35\% in master's degrees, presenting a low UCs average (respectively, 5.7 and 6.3).

Communication Sciences, CS, and Corporate Communication, CC, present values that are more interesting: internships are mandatory in over two-third of cases, both in CS and in CC master's courses. Comparing CC's masters to ME, CC pay a higher attention to a practical education; however, values are still low in both cases. In our opinion, the management component in $\mathrm{CC}$ and $\mathrm{ME}$ requires concrete experience and soft skills development, which are directly learned in work environments.

Except for MED and some isolated cases, there is a fragmentation of the internship experience, which crosses all disciplinary areas. Considering that, a single academic course in any CoS corresponds to 9 or 12 credits, our data suggest even less attention to internships compared to the effort required for an exam.

The result is a scenario where the university makes little or no innovative effort in relation to the external environment, be it due to mistrust towards practical knowledge or for a lack of government efforts to promote this type of experience. Universities, in fact, delegate professors who often lack the necessary preparation (entrepreneurial and/or managerial) to tutor interns, who have great difficulty in monitoring the process and developing solid relationships with hosting subjects. To be truly effective, it is necessary to implement dedicated financial resources and quality evaluations, without depending on individual contributions and initiatives.

This is in line with the few available data that try to link the extent of internships and the employability of students. For example, Alma Laurea (2014) affirms that 56 young graduates out of 100, having had a curricular internship experience, have a $14 \%$ higher employment probability at the end of their studies, compared to those who did not do an internship, thus indicating how internships have a significant employment advantage.

In addition, ANVUR (2014) only reports that, during the academic year 2011/2012, 95.6\% of the 90 reviewed Italian universities had activated an internship and traineeship service, without distinguishing between services exclusively dedicated to curricular internships and services for post-degree internships. This survey was based on the traditional distinction between curricular internships and occupational-oriented internships, consisting of job placements, thus revealing a cultural perspective where the only meaning attributed to internships is limited to 
their impact on employment perspectives. However, when considering the triple helix approach, and the associated opportunity for knowledge growth in society, stimulated by practical experience, the overall value of this work-based learning experience increases.

\section{Implications, Limitations and Future Research}

In a scenario characterized by a high level of technological innovation, learning by doing could represent a new frontier for universities. Guerrero et al. (2015) developed a model to measure the economic impact of entrepreneurial and traditional universities in the UK. The results show that the most entrepreneurial universities (i.e. the Russel Group) contribute to economic development on an international level, strongly increasing competitiveness thanks to qualified research and a widespread entrepreneurial mentality. On the other hand, the most traditional universities (which represent the control group in the research) still contribute to development, but only on local (regional) and national levels. It would be interesting to create a similar research model for Italy.

Our database is a first step in this direction. The data on curricular internships show a lack of interest in this work-based learning experience. In opposition, our review of literature shows that internships are among the fundamental elements to move universities towards a more entrepreneurship mode. We contend that the simple technological transfer translated into spin-offs and patents, does not suffice for the Italian case in the detection of evolutionary trends. It is thus necessary to consider both the direct and indirect contributions that a learning-by-doing oriented teaching can give to the consolidation of the "knowledge capital" from businesses. We are aware that internship is just one of several contact points with business world, if we consider the great number of different initiatives (enterprise creation, crowdfunding challenges, etc.) that universities propose to their students. The interest of businesses in strongly supporting curricular internships and other forms of co-curricular experiences within wide-ranging projects, shared with universities and regional/national institutions would be a strategic push towards the recognition of the value of a triple helix approach. In this scenario, the universities' role, according to Kalar and Antoncic (2015), is not only to generate knowledge, but also mainly to diffuse it within the social and industrial textures. The examined literature, especially for North America, agrees on the fact that early exposure of undergraduates to internships and learning experiences in firms favours the propensity by firms to select young qualified students as well as the possibility for students to undertake entrepreneurial careers on their own. Although much of European institutions are investing in internships, our study highlights the low interest of Italian universities in the phenomenon, which emphasizes their difficulty in becoming entrepreneurial.

Regarding the limitations of our study, we did not analyse the data related to students' careers, in order to correlate exam results before and after the internship experience, or to evaluate the impact of the experience on the development of learning skills. We also did not analyse, through reports related to the internships, the skills developed and later used in the job market. Other important data we did not collect concern the amount of time taken to achieve graduation and employment rates. We also did not collect data on enterprises and institutions where the internships were conducted, which would have enabled us to evaluate their validity from an entrepreneurial standpoint. We also did not take into consideration educational projects including internship-related activities. However, these limitations and the lack of qualitative data (both on students', university offices and employers' sides) could stimulate further analysis to have a clear picture of the phenomenon. Future research should include qualitative interviews with students, university managers and employers to ascertain the favourable outcomes of curricular internships in an integrated way. These additional insights seem essential if universities, government and participating firms are interested in modifying and giving adequate weight to the current internship programs and other related activities to better meet the students' career plans.

In terms of policy implications, our study aims to be a starting point to monitor the internship phenomenon in Italian universities. We propose building a national institutional observatory, which would collect data related to internships on a yearly basis, to favour the passage to an entrepreneurial university, at least for those universities who have this ambition. As previously mentioned, this would mean identifying not only which and how many spin-offs or patents have been created by universities, but also to ascertain how many students have undertaken entrepreneurial courses, in order to improve learning conditions during internships. Equally interesting would be to enlarge the scope of the database including data of all EU and non-EU universities that participate in Erasmus + programs in order to facilitate mechanisms that integrate and maximise the benefits of traineeship spent abroad. These types of initiatives would favour an increase in the professional network that improves and optimises communication and links between universities and firms, thus encouraging the development of those soft skills that are crucial to the education of future leaders of society. 


\section{References}

ACEI (Advisory Committee on Entrepreneurship and Innovation). (2015). Broadening our Impact: Becoming THE Entrepreneurial University. Calgary, Canada: University of Calgary.

Alberti, F. (1999). La formazione imprenditoriale: teoria e prospettive di ricerca. LiucPapers, 65. Serie Piccola e Media Impresa 3, luglio-agosto.

Alfonsi, C. R., \& Dilorenzo, P. (2012). L'evoluzione dei rapporti tra università, territorio and mondo del lavoro in Italia, Roma, Italy: CRUI Foundation.

Alma, L. (2014). Condizione occupazionale dei Laureati, XVI indagine 2013, Bologna, Italy.

ANVUR. (2014). Rapporto sullo stato del sistema universitario e della ricerca 2013, Roma, Italy.

Bak, M. (Ed.) (2014). Emerging Modes of Cooperation between private sector Organizations and Universities. National Reports and Case Study Summaries (Survey Interview Summaries). EMCOSU project report.

Becker, G. S. (1975). Human Capital. A Theoretical and Empirical Analysis with Special Reference to Education. Chicago, United States: The University Chicago Press.

Binder, F. J., Baguley, T., Crook, C., \& Miller, F. (2015). The academic value of internships: Benefits across disciplines and student backgrounds. Journal of Contemporary Educational Psychology, 41, 73-82. http://dx.doi.org/10.1016/j.cedpsych.2014.12.001

Blanco, E. J. F., \& Latorre, M. J. M. (2012). Practical and pre-professional teaching in the framework of the administrative sciences. Innovar. Revista de ciencias administrativas y socials, 22(45), 69-82.

Bowen, G. A. (2008). Naturalistic inquiry and the saturation concept: a research note. Qualitative Research, 8 , 137-152. http://dx.doi.org/10.1177/1468794107085301

Burke, D. D., \& Carton, R. (2013). The Pedagogical, Legal, and Ethical Implications of Unpaid Internships. Journal of Legal Studies Education, 30(1), 99-130. http://dx.doi.org/10.1111/j.1744-1722.2013.01115.x

Cameron, C., Freudenberg, B., \& Brimble, M. (2013). Making economics real - The economics internship. International Review of Economics Education, 13, 10-25. http://dx.doi.org/10.1016/j.iree.2013.04.011

Cannon, E. P., \& Frank, D. (2009). Promoting Ego Development and Multicultural Competence during Internship. International Journal for the Advancement of Counselling, 31(3), 199-211. http://dx.doi.org/10.1007/s10447-009-9078-0

Carter, D. F., Ro, H. K., Alcott, B., \& Lattuca, L. R. (2016). Co-Curricular Connections: The Role of Undergraduate Research Experiences in Promoting Engineering Students' Communication, Teamwork, and Leadership Skills. Research in Higher Education, 57(3), 363-393. http://dx.doi.org/10.1007/s11162-015-9386-7

CEMS. (2010). Community of European Management Schools - Student Board, Internship Survey Analysis, MIM Affair.

Cennini, C. (1859). Il libro dell'arte o Trattato della pittura. Le Monnier. Firenze, Italy. [Original work published 1400].

Chang, J., Yeh, Y., \& Tien, Y. (2015). Entrepreneurial Competencies and Entrepreneurship Cultivation Among College Students: A Case Study of Internship Institutions. The Electrical Engineering and Computer Science Industries. Paper presented at the 2nd International Conference on Advanced Education Technology an Management Science (AETMS 2014), Hong Kong, 175-179. Lancaster, United Kingdom: Destech Publications Inc.

Cheong, A. L. H., Yahya, N. B., Shen, Q. L., \& Yen, A. Y. (2014). Internship Experience: An In-Depth Interview among Interns at a Business Scholl of a Malaysian Private Higher Learning Institution. Procedia - Social and Behavioral Sciences, 123, 333-343. http://dx.doi.org/10.1016/j.sbspro.2014.01.1431

Ciapetti, L. (2012). Il ruolo dell'Università nelle politiche regionali di innovazione. Istituzioni del Federalismo, 2, 337-362.

Clark, B. (1998). Creating Entrepreneurial Universities: Organizational Pathways of Transformation. New York: Pergamon Press.

Coduras, M. A., Levie, J., Kelley, D. J., Sæmundsson, R. J., \& Schøtt, T. (2010). GEM Global Entrepreneurship Monitor Special Report. A Global Perspective on Entrepreneurship Education and Training, Global 
Entrepreneurship Research Association (GERA).

Coyle, P., Gibb, A., \& Haskins, G. (Eds) (2014). The entrepreneurial university: from concept to action, NCEE. CRUI Foundation. Tirocini formativi. L'esperienza della fondazione CRUI, Roma, Italy.

D’Abate, C. P., Youndt, M. A., \& Wenzel, K. E. (2009). Making the Most of an Internship: An Empirical Study of Internship Satisfaction. Academy of Management Learning \& Education, 8(4), 527-539. http://dx.doi.org/10.5465/AMLE.2009.47785471

Daugherty, E. L. (2011). The public relations internship experience: A comparison of student and site supervisor perspectives. Public Relations Review, 37, 470-477. http://dx.doi.org/10.1016/j.pubrev.2011.09.010

De Grez, L., \& Van Lindt, D. (2012). The Influence of a "Learning-by-Doing” Program on Entrepreneurial Perceptions of Economics Students. In Vivas, C., \& Lucas, F. (Eds). Paper presented at the $7^{\text {th }}$ European Conference on Innovation and Entrepreneurship, Santarem, Portugal.

Della, V. M. (2009). Lo stage universitario nell'economia della conoscenza. Annali dell'Università degli Studi Suor Orsola Benincasa, 2, 555-586.

Dilts, J. C., \& Fowler, S. M. (1999). Internships: preparing students for an entrepreneurial career. Journal of Business \& Entrepreneurship, 11(1), 51-63.

Dodescu, A. O., Pop-Cohuţ, I. C., \& Chirilă, L. F. (2014). Do practise stages encourage students in Economics to practice entrepreneurship? Practeam project. Procedia Economics and Finance, 15, 1083-1090. http://dx.doi.org/10.1016/S2212-5671(14)00560-7

Dohn, J., Pepper, D. W., \& Sandgren, E. (2005). Creating innovative curricula: Developing new programs with new paradigms. International Journal of Engineering Education, 21(2), 233-238.

Dombrowski, R. F., Smith, K. J., \& Wood, B. G. (2013). Bridging the education-practice divide: The Salisbury University auditing internship program. Journal of Academic Education, 31, 84-106. http://dx.doi.org/10.1016/j.jaccedu.2012.12.003

Etzkowitz, H. (1983). Entrepreneurial Scientists and Entrepreneurial Universities in American Academic Science. Minerva, 21(2-3), 198-233. http://dx.doi.org/10.1007/BF01097964

Etzkowitz, H. (1990). The second academic revolution: the role of the research university in economic development. In Cozzens S., Healey P., Rip A., Ziman J. (Eds.), The research system in transition, II, 109-124. Boston: Kluwer Academic Publishers. http://dx.doi.org/10.1007/978-94-009-2091-0_9

Etzkowitz, H. (2002). MIT and the Rise of Entrepreneurial Science. London: Routledge. http://dx.doi.org/10.4324/9780203216675

Etzkowitz, H. (2003). Research groups as 'quasi-firms': the invention of the entrepreneurial university. Research Policy, 32, 109-121. http://dx.doi.org/10.1016/S0048-7333(02)00009-4

Etzkowitz, H., \& Leydesdorff, L. (2000). The dynamics of innovation: from national systems and "Mode 2" to a Triple Helix of University-Industry_Government Relations. Research Policy, 29(2), 109-123. http://dx.doi.org/10.1016/S0048-7333(99)00055-4

European Youth Forum. (2011). Interns revealed. A survey on internship quality in Europe. Bruxelles, Belgium.

Fayolle, A., \& Redford, D. T. (Eds.) (2007). Handbook of Research in Entrepreneurship Education. Cheltenham: Edward Elkgar Publishing.

Fayolle, A., Gailly, B., \& Lassas-Clerc, N. (2006). Effect and Counter-effect of Entrepreneurship Education and Social Context on Student's Intentions. Estudios de Economía Aplicada, 24(2), 509-523.

Frank, A. I. (2005). Developing entrepreneurship skills in the context of higher education. Paper presented at the Built Environment Education (BEE) Conference, London, United Kingdom.

Frasquet, M., Calderòn, H., \& Cervera, A. (2012). University-industry collaboration from a relationship marketing perspective: an empirical analysis in a Spanish University. Higher Education, 64(1), 86-98. http://dx.doi.org/10.1007/s10734-011-9482-3

Friedmann, J., Hackenbrock, V., Hipp, D., Klawitter, N., Koch, J., \& Lakotta, B. et al. (2004). Wo studieren die besten? Spiegel, 57(48), 178-200.

Galeano, N., Morals, M. R., \& Cantu, F. J. (2012). Developing Research Skills in Undergraduate Students through an Internship Program in Research and Innovation. International Journal of Engineering Education, 
28(1), 48-56.

Gao, S., \& Gao, Y. (2012). Electronic Commerce Teaching Resources Platform Construction Solution Study. In AA.VV. Eleventh Wuhan International Conference on e-Business, 46.

Gary, K., Razdan, A., Koehnemann, H., Sannier, A., \& Kagan, A. (2008). Work-in-Progress: Embedding Entrepreneurship in the Computing Curricula. Paper presented at the IEEE Frontiers in Education Conference, 1-3, 1389-1390. http://dx.doi.org/10.1109/fie.2008.4720613

Gault, J., Leach, E., \& Duey, M. (2010). Effects of business internships on job marketability: the employers' perspective. Education Training, 52(1), 76-88. http://dx.doi.org/10.1108/00400911011017690

Gault, J., Redington, J., \& Schlager, T. (2000). The benefits of undergraduate business internships: implications for the student, university, and business community. Journal of Marketing Education, 22(1), 45-53. http://dx.doi.org/10.1177/0273475300221006

Gorman, G., Hanlon, D., \& King, E. (1997). Some research perspectives on entrepreneurship education, enterprise education and education for small business management: a ten-year literature review. International Small Business Journal, 15(3), 56-77. http://dx.doi.org/10.1177/0266242697153004

Graham, R. (2014). Creating university-based entrepreneurial ecosystems. Evidence from emerging world leaders. MIT Skoltech Initiative.

Gras, J. M. G., Lapera, D. R. G., Solves, I. M., Jover, A. J. V., \& Azuar, J. S. (2008). An empirical approach to the organizational determinants of spin-off creation in European universities. International Entrepreneurship and Management Journal, 4, 187-198. http://dx.doi.org/10.1007/s11365-007-0061-0

Guerrero, M., \& Urbano, D. (2012). The development of an entrepreneurial university. The Journal of Technology Transfer, 37(1), 43-74. http://dx.doi.org/10.1007/s10961-010-9171-x

Guerrero, M., \& Urbano, D. (2014). Entrepreneurial University in Two European Regions: A Case Study Comparison. The Journal of Technology Transfer, 39(3), 415-434. http://dx.doi.org/10.1007/s10961-012-9287-2

Guerrero, M., Cunningham, J. A., \& Urbano, D. (2015). Economic impact of entrepreneurial universities' activities: An exploratory study of the United Kingdom. Research Policy, 44, 748-764. http://dx.doi.org/10.1016/j.respol.2014.10.008

Guerrero, C. M., Kirby, D., \& Urbano, D. (2006). A literature review on entrepreneurial universities: An institutional approach. Paper presented at the 3rd Conference of Pre-communications to Congresses, University of Barcelona, Barcelona, Spain.

Holyoak, L. (2013). Are all internship beneficial learning experiences? An exploratory study. Education + Training, 55(6), 573-583. http://dx.doi.org/10.1108/ET-02-2012-0024

Hoyle, J., \& Goffnett, S. (2013). A Stakeholder Framework for Designing and Directing Effective Marketing Internships. Journal for Advancement of Marketing Education, 21(1), 1-15.

Hurst, J. L., \& Good, L. K. (2010). A 20-year evolution of internships: implications for retail interns, employers and educators. The International Review of Retail, Distribution and Consumer Research, 21(1), 175-186. http://dx.doi.org/10.1080/09593960903498342

Hynie, M., Jensen, K., Johnny, M., Wedlock, J., \& Phipps, D. (2011). Student internships bridge research to real world problems. Education + Training, 53(2-3), 237-248. http://dx.doi.org/10.1108/00400911111102351

Ilsbroux, I. (2012). Entrepreneurial engineering experiences for bridging the gap between university college and industry. In Chova L. G, Martinez A.L., Torres I.C. (Eds.). International Technology, Education and Development Conference, Valencia, Spain. 2189-2195.Valencia, Spain: INTED Proceedings.

Ilsbroux, I., \& Sammels, E. (2011). Providing opportunities for personal and career development of engineering students. In Torres, I. C., Chova, L.G., \& Martinez, A. L. (Eds.). Paper presented at the 4th International Conference of Education, Research and Innovation, Madrid, Spain. Valencia, Spain: IATED Publisher.

Kalar, B., \& Antoncic, B. (2015). The entrepreneurial university, academic activities and technology and knowledge transfer in four European countries. Technovation, 36-37, 1-11. http://dx.doi.org/10.1016/j.technovation.2014.11.002

Khan, S. (2012). The One World Schoolhouse. Education Reimagined. New York, United States: Twelve Hachette Book Group. 
Kim, E. B., Kim, K., \& Bzullack, M. (2012). A survey of internship programs for management undergraduates in AACSB-accredited institutions. International Journal of Educational Management, 26(7), 696-709. http://dx.doi.org/10.1108/09513541211263755

Kirby, D., Urbano, D., \& Guerrero, M. (2011). Making University More Entrepreneurial: Development of a Model. Canadian Journal of Administrative Science, 28, 302-316. http://dx.doi.org/10.1002/cjas.220

Leydesdorff, L. (2012). The Triple Helix of University-Industry-Government Relations. In Encyclopedia of Creativity, Innovation, and Entrepreneurship, 1844-1851. New York: Springer.

Liñán, F., Urbano, D., \& Guerrero, M. (2011). Regional variations in entrepreneurial cognitions: Start-up intentions of university students in Spain. Entrepreneurship \& Regional Development: An International Journal, 23(3-4), 187-215. http://dx.doi.org/10.1080/08985620903233929

Mann, L. L., \& Blum, I. (2004). Entrepreneurship of dietetic program graduates. Canadian Journal of Dietetic Practice and Research, 65(4), 166-173. http://dx.doi.org/10.3148/65.4.2004.166

Mayhew, M. J., Simonoff, J. S., Baumol, W. J., Wiesenfeld, B. M., \& Klein, M. W. (2012) Exploring innovative entrepreneurship and its ties to higher educational experiences. Research in Higher Education, 53(8), 831-859. http://dx.doi.org/10.1007/s11162-012-9258-3

McDonald, P. R., Roy, A., \& Chaguturu, R. (2011). The University of Kansas High-Throughput Screening Laboratory. Part I: meeting drug-discovery needs in the heartland of America with entrepreneurial flair. Future Medicinal Chemistry, 3(7), 789-795. http://dx.doi.org/10.4155/fmc.11.36

Meyers, A. D., \& Pruthi, S. (2011). Academic entrepreneurship, entrepreneurial universities and biotechnology. Journal of Commercial Biotechnology, 17, 349-357. http://dx.doi.org/10.1057/jcb.2011.22

Mihail, D. M. (2006). Internships at Greek universities: an exploratory study. Journal of Workplace Learning, 18(1), 28-41. http://dx.doi.org/10.1108/13665620610641292

Molas, G. J., Salter, A., Patel, P., Scott, A., \& Duran, X. (2002). Measuring third stream activities. Final report to the Russell Group of Universities. SPRU: University of Sussex.

Nadan, J. S. (2014). Using innovation Science to Minimize Entrepreneurial Risk. Paper presented at the IEEE Innovations in Technology Conference (INNOTEK), Warwick, United Kingdom: IEEE. http://dx.doi.org/10.1109/innotek.2014.6877372

Narayanan, V. K., Olk, P. M., \& Fukami, C. V. (2010). Determinants of Internship Effectiveness: An Exploratory Model. Academy of Management Learning \& Education, 9(1), 61-80. http://dx.doi.org/10.5465/AMLE.2010.48661191

Nitu-Antonie, R. D., Sirghi, N., Hategan, C. D., Feder, E. S., \& Socoliuc, O. R. (2014). Education - Vector of Entrepreneurship development. Transformation in Business and Economics, 13(3), 8-369.

OIEEDA (Office of Innovation \& Entrepreneurship Economic Development Administration), \& NACIE (National Advisory Council on Innovation and Entrepreneurship). (2013). The innovative and Entrepreneurial University: Higher Education, Innovation \& Entrepreneurship in Focus, United States, Department of Commerce.

Pavlin, S. (2014). EMCOSU-Emerging Modes of Cooperation between private sector Organizations and Universities.

Perrin, R. (2012). Intern Nation: How to Earn Nothing and Learn Little in the Brave New Economy. London: Verso.

Poh-Kam, W., Yuen, P. H., \& Singh, A. (2007). Towards an "Entrepreneurial University" Model to Support Knowledge-Based Economic Development: The Case of the National University of Singapore. World Development, 35(6), 941-958. http://dx.doi.org/10.1016/j.worlddev.2006.05.007

Powers, J. B. (2004). R\&D funding sources and university technology transfer: What is stimulating universities to be more entrepreneurial? Research in Higher Education, 45(1), 1-23. http://dx.doi.org/10.1023/B:RIHE.0000010044.41663.a0

Renganathan, S., Abdul, K. Z. A. B., \& Li, C. S. (2012). Students perception of Industrial internship programme. Education+Training, 54(2-3), 180-191. http://dx.doi.org/10.1108/00400911211210288

Riviezzo, A., \& Napolitano, M. R. (2014). Orientamento imprenditoriale: un'indagine tra le università italiane. Sinergie. Italian Journal of Management, 93, 193-212. 
Roper, S. (2013). Entrepreneurship. A global perspective. London \& New York: Routledge.

Sabato J., \& Botana, N. (1968). La ciencia y la tecnologia en el desarollo futuro de América Latina. Revista de Integratiòn, 3, 15-36.

Sascha, G. W., Praveen P. K., \& Achim, W. (2013). University Departments and Self-Employment Intentions of Business Students: A Cross-Level Analysis. Entrepreneurship Theory and Practice, 37(2), 175-200. http://dx.doi.org/10.1111/j.1540-6520.2011.00460.x

Schulte, P. (2004). The entrepreneurial university: A strategy for institutional development. Higher Education in Europe, 29(2), 187-191. http://dx.doi.org/10.1080/0379772042000234811

Schwab, K. (2013). The Global Competitiveness Report 2013 -2014. Full Data Edition, World Economic Forum (Ed.), Switzerland, SRO-Kundig.

Shin, Y., Lee, K., Ahn, J., \& Jung, J. (2013). Development of Internship \& Capstone Design Integrated Program for University-Industry Collaboration, 6th International Forum on Engineering Education (IFEE 2012). Procedia - Social and Behavioral Sciences, 102, 386-391. http://dx.doi.org/10.1016/j.sbspro.2013.10.753

Short, J. (2009). The art of writing a review article. Journal of Management, 35, 1312-1317. http://dx.doi.org/10.1177/0149206309337489

Slaughter, S., \& Leslie, L. L. (1997). Academic Capitalism: Politics, Policies and the Entrepreneurial University. Baltimore: Johns Hopkins University Press.

Taylor, M. S. (1988). Effects of college internships on individual participants. Journal of Applied Psychology, 73(7), 393-401. http://dx.doi.org/10.1037/0021-9010.73.3.393

Tholen, G., Brown, P., Power, S., \& Allouch, A. (2013). The role of networks and connections in educational elites' labour market entrance. Research in Social Stratification and Mobility, 34, 142-154. http://dx.doi.org/10.1016/j.rssm.2013.10.003

Todorovic, W. Z., McNaughton, R. B., \& Guild, P. D. (2011). ENTRE-U: an entrepreneurial orientation scale for universities. Technovation, 29(1), 128-137. http://dx.doi.org/10.1016/j.technovation.2010.10.009

Vega-Jurado, J., Fernandéz-de-Lucio, I., \& Huanca, R. (2008). University-industry relations in Bolivia: implications for university transformations in Latin America. Higher Education, 56(2), 205-220. http://dx.doi.org/10.1007/s10734-007-9098-9

Walshok, M. L., \& Shapiro, J. D. (2014). Beyond Tech Transfer: A More Comprehensive Approach to Measuring the Entrepreneurial University. In Corbett, A. C., Siegel, D. S., \& Katz, J. A. (Eds.). Academic Entrepreneurship: Creating an Entrepreneurial Ecosystem (Advances in Entrepreneurship, Firm Emergence and Growth), 16, 1-36. Bingley: Emerald. http://dx.doi.org/10.1108/s1074-754020140000016001

\section{Notes}

${ }^{\mathrm{i}}$ In particular, the study underlines how the University Reform Movement (URM), occurring during the first half of the twentieth century, considers universities as research and teaching institutions, active in the solution of social problems. They are considered as the fit place for social debate, but not to establish relations with private enterprises. Only during the 1960s, with the approach defined as Sabato Triangle - see Sabato \& Botana (1968) -, was there agreement on the fact that science and technology are development agents and they depend on the coordinated action of three subjects. In 1990, the Triple Helix model was also adopted in Latin America, and time has favoured relations between subjects, but an internal resistance, derived by URM, still exists.

${ }^{i i}$ There are also cases of internships being experiences of thesis elaboration associated to a study or research activity at a university laboratory, especially in the bio-chemical field.

iii The list includes 96 bodies, of which 5 do not directly offer $\operatorname{CoS}$ but parallel courses, or just $\mathrm{PhD}$ courses, which is why we considered 91 universities (including 11 online and 30 private ones).

${ }^{\text {iv }}$ The professional orders related to a master's degree are: notaries and lawyers (LW), actuaries and commercial law experts (ME), surgeons and odontologists, pharmacists, obstetricians, veterinarians, nurses, medical radiology technicians (MED), psychologists (PSY), social workers (SS), engineers (ENG), chemists and biologists (MS), architects (AR), agrarian experts, geologists (EAS), agronomists (AGENS), business consultants (different master degrees), nutritional technologists (AGENS). 


\begin{tabular}{cc}
\hline Appendix A. Table of Scientific Areas & \\
\cline { 2 - 3 } INITIALS & SCIENTIFIC AREAS \\
\hline AE & Arts and Entertainment \\
AGENS & Agricultural, Environmental and Nutrition Sciences \\
AR & Architecture and Design \\
CC & Corporate Communication \\
CH & Cultural Heritage \\
CPS & Computer Science \\
CS & Communication Sciences \\
EAS & Earth Sciences \\
ED & Education \\
ENG & Engineering \\
L & Languages \\
LIT & LW \\
ME & Literature, Philosophy, History, Religion \\
MED & Management and Economics \\
MS & Medical, Health and Sport Sciences \\
PSS & Mathematics, Physics, Biology and Chemistry \\
PSY & Political and Social Sciences \\
SS & Psychology \\
T & Social Sciences \\
\end{tabular}

\section{Copyrights}

Copyright for this article is retained by the author(s), with first publication rights granted to the journal.

This is an open-access article distributed under the terms and conditions of the Creative Commons Attribution license (http://creativecommons.org/licenses/by/4.0/). 